International Journal of Instruction e-ISSN: 1308-1470 • www.e-iji.net
October $2020 \bullet$ Vol.13, No.4

p-ISSN: 1694-609X

pp. $781-798$

Received: 13/10/2019

Revision: 14/05/2020

Accepted: 03/06/2020

OnlineFirst:22/08/2020

\title{
Teacher Educators' Perspectives and Experiences towards Differentiated Instruction
}

\section{Tamirat Gibon Ginja}

Ph.D. Candidate, Shaanxi Normal University, Xi'an, China, gibontamirat@snnu.edu.cn

\section{Xiaoduan Chen}

Prof., Shaanxi Normal University, Xi'an, China, chenxiaoduan@snnu.edu.cn

This study was conducted to investigate teacher educators' perspectives and their experiences toward differentiated instruction employing an explanatory sequential mixed research design. By administering a random sampling and purposive sampling technique, 67 teacher educators from three higher institutions. Data were collected using a questionnaire and interview. The results indicated that teacher educators recognised the differentiated instruction approach as essential to use in a diverse classroom. Increased motivation, improved relationship between learners and teacher educators, and narrowed achievement gap of learners were some reported attainments. On the other hand, the limited number of trained teacher educators, miss-conception of differentiated instruction, the large size of the class, limited access to professional development training, and shortage of facilities were identified as hindering factors. Finally, the provision of adequate practical courses in teacher training programs, conducting awareness through various academic events, and fulfilling required facilities and educational inputs were recommended.

Keywords: differentiated instruction, instructional strategies, teacher educators, need of learners, educators' perspective

\section{INTRODUCTION}

Researches affirm that differentiating instruction based on learners' needs is much harder for Ethiopian teacher educators, rather they are teaching in a 'one-size-fits-all' approach (Joshi \& Verspoor, 2012; Melese, 2019; Melesse, 2016). According to the report of the Ethiopian Ministry of Education (MoE), the graduation rate of regular undergraduate students is as low as 79\% and it has been noted as an implication of low quality of instruction (MoE, 2015). The Ministry of Education explains the low quality of learning outcomes; and high dropout and repetition rates mirror the existence of lessskilled teacher educators in terms of how to teach (MoE, 2015).

Citation: Ginja, T. G., \& Chen, X. (2020). Teacher Educators' Perspectives and Experiences towards Differentiated Instruction. International Journal of Instruction, 13(4), 781-798. https://doi.org/10.29333/iji.2020.13448a 
Ethiopia is one of the countries more than ever diversified, in which students might need to be tailored differentiated instruction. Diversity in the classroom includes aspects of age, ethnicity, gender, physical abilities, religious orientation, socio-economic status, family status, etc. Students with all these ranges of differences are learning together using a 'one-size-fits-all' approach in Ethiopia (Melesse, 2016). It requires teacher educators' attention to minimize the probable reasons for slow learning in such a context. Adapting instructional design into different needs of learners is a vigorous factor that influences the effectiveness of learning processes (Mien, den, \& David, 2003). But due to the increasing demographic characteristics of contemporary classrooms in Ethiopian higher education, teacher educators are faced with a challenge to plan effective instruction that focuses on the needs of diverse learners (Melese, 2019).

Many scholars agree on the significance of differentiated instruction in a learning process and the term differentiated instruction is nothing new indeed (Gregory \& Kuzmich, 2004; Subban \& Round, 2015; Theisen, 2002; Carol A. Tomlinson, 1999, 2001, 2005). The predominant goal of differentiated instruction is for teachers to maximise the potential of all learners by proactively designing learning experiences in response to the needs of diverse learners (Santangelo \& Tomlinson, 2012). As global experiences inform that teacher educators play an effective role to understand and to improve the instructional process of their respective countries' education (Sultana, Yousuf, Din, \& Rehman, 2011). However, now a day heterogeneity in classes increases, the challenge of tailoring instruction to learners becomes increasingly difficult (Smets \& Struyven, 2018); and teachers of some countries are teaching under diversified circumstances using a 'one-size-fits-all' approach (Santangelo \& Tomlinson, 2012).

On the other hand, some teacher educators argue that differentiating instruction is too difficult to apply and should no longer be suggested as a means for supporting the diverse needs of students in the classroom (Delisle, 2015). In support of this, informal discussions held with some teacher educators who have long years of teaching experience at the Colleges of Teacher Education and Universities confirmed that adopting a differentiated instructional approach in Ethiopian Universities context seems limited (Melese, 2019).

These types of experiences, different understandings about the nature of differentiation, and lack of sufficient studies in the Ethiopian context made us curious to research this topic. Unfortunately, some teacher educators teach learners without having much formal knowledge of how differentiating instruction. Many teacher educators know how they learn best, but do not necessarily consider how their students learn and if the way they teach is predicated on enabling learning to happen. Moreover, our personal experience and professional belief led us to explore teacher educators' perspectives and experiences in differentiating instruction in the context of selected Ethiopian teacher education institutions. To this end, the following research basic questions premeditated: (1) to what extent do teacher educators understand the concepts of differentiated instruction? (2) how do teacher educators differentiate instruction to meet the needs of all students? and (3) what is the effectiveness of using differentiated instruction model in pre-service teacher education program as perceived by teacher educators? The objective of the 
study is to investigate teacher educators' perspective of differentiated instruction and their experiences in how they are differentiating instruction in their classes. The implication of this study is awakening teacher educators, policymakers and educational authorities who can address the gaps accordingly.

\section{LITERATURE REVIEW}

Instruction is a deliberate attempt to structure a learning environment so that learners will acquire specified knowledge or skill and its purpose is to promote learning (Merrill, 2013). Tomlinson defines differentiated instruction as an educator's reaction to student's needs guided by general standards of differentiation, for example, respectful tasks, flexible grouping and continuous assessment and adjustment (Tomlinson, 1999). Differentiated instruction is one of the models of teaching in which teachers actively plan for learners' differences so that all learners can best learn. It is the way of instruction ensuring that what a learner learns, how he or she learns, and how demonstrates what he or she has learned (Nordlund, 2003; Tomlinson, 2005; Tomlinson \& Imbeau, 2011). Differentiating instruction to meet those diverse learners is a philosophy that teachers embrace; and ways to differentiate learning processes that are appropriate at different times in different situations with different learners (Gregory \& Kuzmich, 2004). Thus, according to Tomlinson (1999), teachers can differentiate learning environment, content, process, and product according to students' readiness, interests, and learning profile. Students who are the same age differ in their learning readiness, their interests, and their styles of learning, their experiences, and their life circumstances (Audet \& Jordan, 2005; Livingston, 2016; C. A Tomlinson, 2000). These key elements of differentiated instruction described as follows.

\section{Key Elements of Differentiated Instruction}

Learner readiness refers to how probable a learner is to learn. Vygotsky (1978) suggests that teachers should teach within the range of challenges in which a learner can progress because the task is neither too hard nor too easy. It is a call for learners' learning readiness. A teacher has to pay attention to student readiness as an important component of differentiated instruction. Its goal is to develop a zone of proximal development that learners must actively interact socially with a knowledgeable adult or capable peers (Vygotskij, 1986). In the case of learners' readiness, teachers are required to utilize learners' interests and keep their motivation since maintaining learners' interest is an essential element in the teaching-learning process; however, it is often a challenge for teachers. As classrooms become more diverse, teachers can no longer think in terms of how can students be motivated. Rather, educators must think about what motivates students and how lessons can be structured properly to meet these diverse interests (Schlechty, 1997). Interests can include personal experiences and strengths, cultural background, and areas of need (Tomlinson \& Imbeau, 2011). When differentiating, teachers consider learner profiles as an important element like readiness and interest. Learner profiles are things about a student that make them unique that identified by a person's gender, culture, learning style, and intelligence preference. It refers to preferred modes of learning in which students will best process what they need to learn (Tomlinson \& McTighe, 2006). Thus, it has been whispered as a teacher provides 
learners with fitting spaces that are conducive to various learning preferences to be effective.

The learning environment can play a significant role in effective instruction process and which takes into account the capabilities and specific learning needs of learners and ensure they are developmentally appropriate for all. The learning environment consists of the routines, procedures, and physical arrangement of the classroom as well as the overall tone or mood that exists among and between the learners and teacher(s) (Santangelo \& Tomlinson, 2012; Subban \& Round, 2015). "The effectively differentiated learning environment is characterized by flexibility (e.g., concerning space, materials, and time) and is carefully constructed to support each learner's need for affirmation, contribution, power, purpose, and challenge" (Santangelo \& Tomlinson, 2012, p. 314). When learners are aware of the roles and expectations placed upon them, and routines and schedules are clear, the efficiency of the classroom becomes improved (Subban \& Round, 2015). Examples of how teachers create a positive environment include

- arranging (and frequently rearranging) the classroom to promote collaboration and cooperation;

- ensuring the availability of resources that reflect learners' diverse backgrounds, interests and reading readiness;

- sharing responsibility for teaching and learning; providing students with individualized attention; adjusting their effect to meet individual learner needs;

- communicating unequivocal respect and concern for each learner;

- demonstrating cultural competence; and

- soliciting and reflecting upon learners' feedback about their classroom experiences (Santangelo \& Tomlinson, 2012; Subban \& Round, 2015).

Teachers can make alterations or modifications in the content of the lesson, provide several ways for the learners to learn the content, and encourage students to show their understanding through diverse products (Theisen, 2002). In this process, according to Tomlinson (2005), the content comprises not only what is taught, but how students access the material taught and suggested as, what is taught should remain relatively constant across learners, with teachers varying how students get access to specified content to address learners' needs.

Process refers to how students make sense or understand the information, ideas and skills practising (Theisen, 2002; Tomlinson, 1999, 2005). On the other hand, it reflects student learning styles and preferences. The process can be differentiated by adapting the multifaceted nature or dynamics of tasks and by engaging learners in critical thinking and reasoning (Theisen, 2002). Thus, it involves providing varied choices at various degrees of difficulty or based on differing student interests; giving options about how 
students express their understanding; varying the learning process relying on how students learn (Tomlinson, 2005).

Product is the way students demonstrate their understanding of the given lesson and this may happen probably in different ways. Hence, teachers can provide learners with a few choices to pick from or students can propose an assignment with teacher approval. The academic criteria must be clear so that the learners understand what is expected of them (McCarthy, 2014). Tomlinson (2005) also suggests that products are culminating assessments that allow learners to demonstrate how much they understand and how well they can apply their knowledge and skills after a significant segment of instruction. Product differentiation should offer students multiple pathways to show mastery of common learning goals (Theisen, 2002).

Researching the ways of learning and differentiated instruction requires a solid understanding of the foundational theories that drive learning, including ideas about how learners learn, what they should learn, and how teachers can enable student learning. In this study, therefore, differentiated instruction is grounded in sociocultural theory (Miller, 2011; Seifert \& Sutton, 2011; Vygotskij, 1986). Sociocultural learning theory holds that experience is critical since it influences the learning process for each learner. Learner's differences produce a range of ideas and problem-solving strategies for students' discussion and reflection (Wilson \& Peterson, 2006). Thus, Vygotskij (1986) proposed that when a child is learning a new skill or solving a new problem, he or she can perform better if accompanied and helped by other/expert than if performing alone. Similarly, Seifert \& Sutton (2011) posit a child's thinking is influenced by relationships with others who are more capable, knowledgeable, or expert than just the learner. This means, according to Vygotskij (1986) and Seifert \& Sutton (2011), an individual learner must be studied within a particular social and cultural context as it is within the context of social relations with others where learning takes place. Therefore, socio-cultural interactions are essential to the development of cognition and necessitate differentiated instruction as well.

The Model of the Zone of Proximal Development (ZPD) is also a central proposition of the socio-cultural learning theory. Vygotsky (1986) posits that the ZPD must be acknowledged to gain an understanding of the real relationship between learning and development. It is the levels of development where a learner is capable of solving problems on her or his own versus the level where the learner can only solve a problem with guidance from others. By providing continued experiences matched to the learner's emerging competencies, the expert [teacher] makes it possible for the learner to appropriate the skills or knowledge that originally resided only with the teacher (Seifert \& Sutton, 2011). Vygotskij (1986) suggests that the teacher remains slightly ahead of the students' actual level of development to remain within the ZPD. If so, the teacher assesses learner's readiness levels and differentiates instruction according to learner needs.

To achieve the above ideal, as researchers suggest, teacher education institutions must put in place systems that support effective teaching through differentiated instruction. Brimijoin (2002) argues that teacher educators in teacher preparation institutions have a 
responsibility to model appropriately differentiated instruction (Carol A. Tomlinson et al., 2003). To this end, we made an effort to explore Ethiopian teacher educator's perspectives and their experiences.

\section{METHOD}

\section{Research Design}

In this study, a mixed-methods design followed. The design combined a qualitative and a quantitative approach assuming one can utilize their respective strengths and escape their respective weaknesses (Lund, 2012). The selection of this design was primarily guided by research questions which very often give clues in wording for what kind of design to choose (Wen, 2004). Specifically, an explanatory sequential mixed methods design was applied during data collection and analysis stages of the study (Creswell, 2013).

\section{Participants}

The study was conducted at Hossana College of Teacher Education (CTE), Dilla CTE and Hawassa University. The institutions designated with a purposive sampling based on their reputations and potential wide-ranging diversity of learners. To ensure impartial study results, the researchers chose almost an equal number of participants from each institution. A random sampling technique employed and 67 teacher educators (22 from two CTEs and 23 from Hawassa University) were included in the study. The sample size accounts for $35 \%$ of teacher educators in their respective schools of Education. Among 67 teacher educators who participated in a questionnaire survey, six (two from each institution) were selected through a purposive sampling technique and interviewed. The criteria for selection were a person who participated in a questionnaire survey, and a person who has a supervisory role such as department head and dean of the school. This strategy helped us to discuss and understand about other teacher educators since they have better exposure to observe their subordinates and deal about DI implementations.

\section{Instruments and Procedure}

The questionnaire used in this research was adapted from the instruments developed and well-validated by Santangelo \& Tomlinson (2012). It reflects Tomlinson's DI model (Santangelo \& Tomlinson, 2012) and the researchers believed that it was highly reliable with a review of the literature. An adoption process did not change the original contents of the instrument rather contextualizing some demographic information. The questionnaire had three sections. The first section included teacher educators' demographics information, section two was a five-point Likert scale question for measuring teachers' attitude while the third section was open-ended questions for teachers to express their concerns and opinions about differentiated instruction approach. Printed copies distributed to selected 69 teacher educators at the three mentioned institutions by one of the researchers and collected. Two teacher educators (one from Hossana CTE and another from Dilla CTE) were not able to return due to their reasons. Travelling to three different institutions which were located at different Zones took more than a week. 
Besides, a semi-structured interview guide was developed after reviewing the literature. Four senior teacher educators from non-target CTE were asked to review and gave their genuine feedback. Based on their comments, the interview guide was restructured and improved. During the analytical process, another researcher was also consulted about data categorizations to the relevant theme and the key elements of DI.

Following the collection of the questionnaires, the interviews were conducted with the teacher educators in their respective offices. A printed version of the interview questions was given to respondents in order to consider the points carefully. During the actual interview, the researcher took notes of their answers on a semi-structured interview guide. After the interview, these notes were immediately organized and shared with interviewees to approve the notes. This process contributed to increasing the research's reliability.

\section{Data Analysis}

The researchers imputed data into the SPSS computer program. Descriptive statistics, including frequencies, percentages, means, and standard deviations were used to analyse. Following each thematic areas of the survey result, considering the key research questions' order and the way how literature review organized, data at open-ended part of the questionnaire, and semi-structured interview were qualitatively analyzed and reported.

\section{FINDINGS}

\section{Demographic Profile}

A total of 67 teacher educators responded to the questionnaire. The teacher educators identified their years of experience, educational qualification, whether received a DI training or not, given training provider/s and their specific department. The participants varied in educational background, qualification, teaching experience and age. A large proportion of respondents $(38.8 \%)$ were beginners with only $1-3$ years of teaching experience. Whereas $32.8 \%$ were well experienced who have been taught for more than 11 years as teacher educators. Among 67 teacher educators, MA degree holders account for $49.3 \%$, BA degree was $31.3 \%$; and $19.4 \%$ constitute for PhD degree holders. As the data revealed, colleges of teacher education and the University were in charge of providing in-service teacher training on DI even if the number of not trained teacher educators $(46.3 \%)$ was almost near to the number of teacher educators who received inservice training on DI $(53.7 \%)$. An equal share of teacher educators who instructing language studies $(n=20)$ and members of pedagogical/educational science $(n=20)$ participated in this study equally. Whereas others from both social science and natural science departments participated with almost comparable proportions.

\section{Understandings Toward Differentiated Instruction}

Teacher educators' understandings are perspectives, conceptions and general knowledge of differentiated instruction. Data analysis involved calculating mainly mean, standard deviations, the frequencies, and percentages of responses falling in each of the 5-point Likert scales. 
Table 1

Teacher Educators' General Knowledge of DI

\begin{tabular}{lllll}
\hline $\mathrm{q} / \mathrm{n}$ & Item & $\mathrm{N}$ & Mean & Std. Deviation \\
\hline 1 & All students learn similarly & 67 & 1.95 & 1.13 \\
2 & All students can be taught in the same way to get the same & 67 & 1.92 & 1.06 \\
& outcome & 67 & 3.67 & 1.13 \\
3 & I have a favourable opinion of DI & 67 & 3.38 & 1.02 \\
4 & I feel confident that I can prepare differentiated lessons & 67 & 2.62 & 1.17 \\
5 & A lack of time holding me back from using DI & 67 & 3.47 & 1.28 \\
6 & DI is less important in a teacher education program & 67 & 2.91 & 1.28 \\
7 & DI is merely for children, not for tertiary level students & 67 & 3.64 & 1.13 \\
8 & If I had more time, I would use DI more often & 67 & 3.55 & 1.17 \\
9 & I rarely have to differentiate for students & 67 & 3.89 & 0.93 \\
10 & I know when DI is effective in my class & 67 & 3.58 & 1.22 \\
11 & Training that I have received on how to DI in my class was & & & \\
& adequate for my needs. & 67 & 3.82 & 1.07 \\
12 & After professional learning, I was motivated to DI. & & \\
\hline
\end{tabular}

Survey items 1-12 addressed teacher educators' general knowledge on DI. As shown in the calculated means and standard deviations where individual item means ranged from 1.95 to 3.89 . They were not agreed with questions 1 and 2 asking about learning at a similar pace and can be taught in the same way to get the same outcome too. Whereas, a high proportion of teacher educators were agreed to questions 10,11 and 12 which account for $74.7 \%, 65.7 \%$ and 73.2 respectively. On the other hand, $59.7 \%$ of teacher educators indicated as they had rarely differentiated for students.

In relation to this, as the qualitative data revealed some of the respondents disclosed their philosophy of teaching that considers students' differences in the instructional process. For instance, Mr. B said, "I feel differentiated instruction is important because every individual learner is unique though the learners may have certain things in common." He extended his explanation saying "I believe the content, the sequence, the format, the difficulty level of activities, the pace of delivery, etc. should be differentiated".

One of the interviewed respondents defined differentiated instruction by stating: "differentiated instruction is teaching to the needs and varying instruction based on a student's ability and their ways of learning." More than half of the questionnaire respondents also reported that teacher educators were good at the theory. Unlikely, some teacher educators reflected obviously as they have limited understanding of the concepts and applications of DI. For example, Mr. D said "I don't know differentiation, I have never been trained. I haven't been trained about DI. They ask us to implement it, but they haven't trained us. I am trying to find information alone." Another interviewed respondent mentioned, "differentiated instruction, in my opinion, means that we are tailoring the lesson to each student's individual needs, and it's kind of impossible to do." This teacher educator said in her extended responses, "I was relieved that differentiated instruction seems so doable and easily interchangeable with the curriculum that I am teaching in my classroom currently." However, she had hesitations about how it would work in the context of mixed learners and not clear about the concept of DI. 


\section{Differentiated Instruction Practices}

Teacher educators' practices of instructional differentiation examined through Likertscale and presented in various sub-groups as follows.

Table 2

Teacher Educators' Practice Regarding Learner's Readiness

\begin{tabular}{cllll}
\hline $\mathrm{q} / \mathrm{n}$ & Item & $\mathrm{N}$ & Mean & $\begin{array}{l}\text { Std. } \\
\text { Deviation }\end{array}$ \\
\hline 13 & $\begin{array}{l}\text { Students in my class differ significantly in relevant } \\
\text { background knowledge. }\end{array}$ & 67 & 3.76 & 0.95 \\
14 & $\begin{array}{l}\text { There is a strong correlation between students' } \\
\text { background knowledge and academic performance. }\end{array}$ & 67 & 3.73 & 1.03 \\
15 & $\begin{array}{l}\text { My understanding of variance in individual students' } \\
\text { background knowledge impacts what/how I teach. } \\
\text { My understanding of variance in individual students' } \\
\text { basic academic skills impacts what/how I teach. }\end{array}$ & 67 & 3.89 & 0.74 \\
\hline
\end{tabular}

The survey items 13-16 illustrated how learner's readiness addressed. As demonstrated in table 2, considerable numbers of teacher educators whispered that students' background knowledge was very important for their academic performance. Accordingly, teacher educators responded to question 13 (agree $46.3 \%$, strongly agree $20.9 \%$ ), question 14 (agree 53.7\%, strongly agree 19.4\%), question 15 (agree 58.2\%), strongly agree $17.9 \%$ ), and question 16 (agree 61.2\%), strongly agree $16.4 \%$ ) optimistically. Likely, survey question 17 concerned that teacher educator's understanding of variance in individual students' interests impacts what/how he/she teaches. As calculated means (3.71) and standard deviations (0.99) of question 17, the strongest agreement was reported for variance in individual students' interests and their teaching methods.

Table 3

Teacher Educators' Practice Regarding Learning Profile

\begin{tabular}{|c|c|c|c|c|}
\hline$q / n$ & Item & $\mathrm{N}$ & Mean & Std. Deviation \\
\hline 18 & $\begin{array}{l}\text { Students in my course differ significantly in their } \\
\text { preferred learning modalities }\end{array}$ & 67 & 3.80 & 0.87 \\
\hline 19 & $\begin{array}{l}\text { There is a strong correlation between students' learning } \\
\text { modalities and their course performance. }\end{array}$ & 67 & 3.71 & 1.04 \\
\hline 20 & $\begin{array}{l}\text { My understanding of variance in individual students' } \\
\text { learning modalities impacts what/how I teach. }\end{array}$ & 67 & 3.83 & 0.82 \\
\hline 21 & $\begin{array}{l}\text { Students in my courses differ significantly in their } \\
\text { preferred grouping orientations }\end{array}$ & 67 & 3.68 & 0.95 \\
\hline 22 & $\begin{array}{l}\text { My understanding of variance in individual students' } \\
\text { grouping orientations impacts what/how I teach. }\end{array}$ & 67 & 3.7015 & 0.92 \\
\hline
\end{tabular}

In table 3 , means and standard deviations were calculated for the Likert-type items concerning the Learning profile. Individual item means ranged from 3.68 to 3.83 . Teacher educators agreed to the notions of almost all learning profile related questions regarding variance in learners' preferred learning modalities. 
Table 4

Teacher Educators' Practice Regarding the Learning Environment

\begin{tabular}{lllll}
\hline $\mathrm{q} / \mathrm{n}$ & Item & $\mathrm{N}$ & Mean & Std. Deviation \\
\hline 23 & $\begin{array}{l}\text { Create activities/assignments to develop a sense of } \\
\text { community among students. }\end{array}$ & 67 & 3.64 & 1.01 \\
24 & $\begin{array}{l}\text { Take deliberate efforts to ensure each student feels } \\
\text { known, welcome, and respected. }\end{array}$ & 3.44 & 1.03 \\
25 & $\begin{array}{l}\text { Take deliberate efforts to make yourself } \\
\text { approachable/available to students. }\end{array}$ & 3.73 & 0.86 \\
26 & $\begin{array}{l}\text { Take deliberate efforts to ensure students participate } \\
\text { consistently and equitably during class. } \\
\text { Take deliberate efforts to enhance students' } \\
\text { attitudes/motivation towards course content. }\end{array}$ & 67 & 3.68 & 0.95 \\
\hline $\begin{array}{l}\text { Follow up privately on behaviours or circumstances of } \\
\text { concern. }\end{array}$ & 67 & 3.89 & 0.78 \\
\hline
\end{tabular}

Practices of teacher educators regarding the learning environment in the above table (4), individual item means ranged from 3.4 to 3.89. In the other words, respondents about $64.2 \%, 53.7 \%, 68.6 \%, 67.1 \%, 68.7 \%$, and $76.1 \%$ were agreed to the questions from 23 to 28 , respectively.

Table 5

Teacher Educators' Practice Regarding Content

\begin{tabular}{|c|c|c|c|c|}
\hline $\mathrm{q} / \mathrm{n}$ & Item & $\mathrm{N}$ & Mean & Std. Deviation \\
\hline 29 & Use text materials that represent a variety of formats. & 67 & 3.61 & 1.02 \\
\hline 30 & $\begin{array}{l}\text { Use text materials that present content at varying levels of } \\
\text { complexity. }\end{array}$ & 67 & 3.61 & 0.99 \\
\hline 31 & $\begin{array}{l}\text { Use text and/or other materials that present content in a } \\
\text { variety of ways }\end{array}$ & 67 & 4.02 & 0.93 \\
\hline 32 & $\begin{array}{l}\text { Use text and/or other materials that reflect students' } \\
\text { interests or experiences. }\end{array}$ & 67 & 3.92 & 0.76 \\
\hline 33 & $\begin{array}{l}\text { Provide supplemental materials/resources to support } \\
\text { students who have difficulty understanding course content. }\end{array}$ & 67 & 3.91 & 1.01 \\
\hline 34 & $\begin{array}{l}\text { Provide supplemental materials/resources to challenge } \\
\text { students who master course content with minimal effort. }\end{array}$ & 67 & 3.56 & 1.07 \\
\hline 35 & $\begin{array}{l}\text { Present course content using visual displays or } \\
\text { demonstrations. }\end{array}$ & 67 & 3.83 & 0.86 \\
\hline 36 & $\begin{array}{l}\text { Present course content using examples that reflect } \\
\text { students' interests or experiences. }\end{array}$ & 67 & 3.70 & 0.88 \\
\hline 37 & $\begin{array}{l}\text { Use strategies to support comprehension and retention of } \\
\text { the content presented in text materials }\end{array}$ & 67 & 3.98 & 0.91 \\
\hline 38 & $\begin{array}{l}\text { Use strategies to support comprehension and retention of } \\
\text { the content presented in class }\end{array}$ & 67 & 3.88 & 0.82 \\
\hline 39 & $\begin{array}{l}\text { Provide supplemental support to candidates who have } \\
\text { difficulty understanding course content }\end{array}$ & 67 & 3.79 & 1.02 \\
\hline 40 & $\begin{array}{l}\text { Create more advanced opportunities for candidates who } \\
\text { master course content with minimal effort. }\end{array}$ & 67 & 3.61 & 1.07 \\
\hline 41 & $\begin{array}{l}\text { Solicit candidate feedback to help select/adjust the content } \\
\text { presented within a given semester. }\end{array}$ & 67 & 3.62 & 1.11 \\
\hline
\end{tabular}


Survey items 29 - 41 addressed teacher educators' practices on content differentiation. As the data revealed, individual item means ranged from 3.56 to 4.02 (see table 5). At least 40 out of 67 and above teacher educators were reported as agreed or strongly agreed to questions 29 to 41 in each case.

Table 6

Teacher Educators' Practice Regarding Process \& Product

\begin{tabular}{|c|c|c|c|c|}
\hline $\mathrm{q} / \mathrm{n}$ & Item & $\mathrm{N}$ & Mean & Std. Deviation \\
\hline 42 & $\begin{array}{l}\text { Design activities that help students understand course } \\
\text { content by interacting with each other. }\end{array}$ & 67 & 3.70 & 1.15 \\
\hline 43 & Use a variety of grouping formats during class. & 67 & 3.73 & 1.05 \\
\hline 44 & $\begin{array}{l}\text { Use a variety of grouping formats for assignments } \\
\text { completed outside of class }\end{array}$ & 67 & 3.56 & 1.07 \\
\hline 45 & $\begin{array}{l}\text { Allow each student to select his/her preferred grouping } \\
\text { format }\end{array}$ & 67 & 3.49 & 0.95 \\
\hline 46 & $\begin{array}{l}\text { Purposefully group students based on their levels of } \\
\text { readiness }\end{array}$ & 67 & 3.58 & 1.08 \\
\hline 47 & $\begin{array}{l}\text { Purposefully group students based on their preferred } \\
\text { learning modalities. }\end{array}$ & 67 & 4.02 & 0.92 \\
\hline 48 & Create activities that offer format options & 67 & 3.79 & 0.94 \\
\hline 49 & $\begin{array}{l}\text { Create activities that allow each student to select a topic of } \\
\text { personal interest. }\end{array}$ & 67 & 3.46 & 1.09 \\
\hline 50 & $\begin{array}{l}\text { Provide supplemental support to students who have } \\
\text { difficulty completing activities. }\end{array}$ & 67 & 3.35 & 1.18 \\
\hline 51 & $\begin{array}{l}\text { Evaluate each candidate based on his/her improvement } \\
\text { during the semester. }\end{array}$ & 67 & 3.35 & 1.12 \\
\hline 52 & $\begin{array}{l}\text { Use three or more forms of assessment to determine course } \\
\text { grades. }\end{array}$ & 67 & 4.19 & 0.87 \\
\hline 53 & $\begin{array}{l}\text { Solicit students' feedback to help create/adjust activities } \\
\text { used within a given semester. }\end{array}$ & 67 & 3.80 & 0.92 \\
\hline
\end{tabular}

As indicated in table 6 , the means and standard deviations were calculated for the Likert-type items concerning process \& product in which individual item means ranged from 3.35 to 4.19 . Questions 47 and 52 were most rated as either agreed or strongly agreed with items whereas questions 45, 50 and 51 disagreed and not decided.

Table 7

Teacher Educators' Practice Regarding Assessment

\begin{tabular}{lllll}
\hline $\mathrm{q} / \mathrm{n}$ & Item & $\mathrm{N}$ & Mean & Std. Deviation \\
\hline 54 & Assess each student's level of readiness. & 67 & 3.62 & 0.91 \\
55 & Assess each student's interests. & 67 & 3.35 & 1.12 \\
56 & Assess each student's learning profile characteristics. & 67 & 3.32 & 1.09 \\
\hline
\end{tabular}

As indicated in table 7, means and standard deviations were calculated for the Likerttype items concerning assessment in which individual item means nearly equal (with only some differences). According to the reported differences, teacher educators varying in their assessment practices and strategies gaining insight into their students' levels of understanding even if the majority of teacher educators were fallen at "agree". 
Moreover, data from the interview and open-ended part of the survey indicated that teacher educators used to employ formal assessment strategies, such as formative evaluation techniques and students' output, to gain insight into their learning needs.

Through interview questions 2, 5, and 8, some differentiation strategies identified. For example, Ms. B recognized a wide range of strategies she used in the course of DI implementation. Some strategies included jigsaw, buzz group, gameplay, cooperative learning, field visit, and giving students a choice in assignments. Also, another interviewed teacher educator mentioned strategies like tiered teaching, think-pair-share, presentation, small groups, songs, and simulation. He considered think-pair-share and small groups the most successful. Another teacher respondent said, "I have comfortably used cooperative groups, with the group leaders helping by tutoring group members." However, as reported by other participants, using such differentiation strategies was limited to only some teacher educators and inconsistently applied.

\section{Effectiveness and Challenges of Using Differentiated Instruction}

Some teacher educators confirmed that how DI influenced to increase the learner motivation in performing academic tasks and building positive relationships between learners and teacher educators. As declared by teacher educators, learners attracted to the way how teacher educators were differentiating. For example, Mr. A expressed his experience saying

I was able to differentiate how my below-level learners grasped the material by paying attention to their learning styles as well as being more succinct in the information needed from them. For my above-level learners, I added more depth to the content necessary for the project. Differentiation was also noticeable in the deliverables required by the students.

Another interviewed participant (head of education department in one College and spoke based on his observation) shared a similar view, saying that

I think it's a very effective method for low-level students. For instance, in the activities which prepared with the station technique, the teacher found the chance to deal with the first station, or the weaker group, very easily...the fact that students in the weaker group could do something with the teacher was very effective on their confidence.

According to the head observation, using DI helped them to address students whose achievement level was varying. He further said, if the classrooms' size is bigger and there are round tables, it'd have been more ideal.

From his saying, one can understand how the facility is important to put principles of DI in practice. DI was well appreciated by teacher educators who started practising in their respective classes. Some of them developed skills through workshops and actual practices. Mr. A supported the use of DI in the classroom and explained that it provides the opportunity for all students to learn: "based on the materials that I have been reading, I understand that differentiating instructions consist of meeting the learner's 
needs." On the other hand, DI implementations encountered challenges in the teacher education program. At open-ended part of the survey, one of the study respondents reported as

It is a time-consuming process. Selecting supplemental materials, adapting them to fit the course or classroom situations, re-sequencing the contents, varying the format/techniques, checking on individual progress, providing sound and timely feedback, etc. are worth extra effort from the educator's side.

Most of the teacher educators were arguing with the use of DI since it is a very timeconsuming exercise with long hours of planning, organizing and presenting in a large classroom setting. One of the teacher educators thought this phenomenon was the main cause of inconsistent (or no) application. The study participants revealed their lack of practical experience in DI. Another participant reported that "there is a misconception that we face over the belief of senior teacher educators that 'the traditional form of teaching is more suitable than new methods to apply' in poor countries like Ethiopian contexts."

\section{DISCUSSION}

Through this an explanatory investigation, we tried to gain perspectives on how teacher educators comprehend and differentiate their instruction. In the context of this study, teacher educators' understandings are thoughts and general knowledge toward a differentiated instruction approach. Participant-teacher educators' profile seems relatively trustworthy in terms of their work experience, the status of DI training and academic qualification even if there were some differences. For example, about 53.7\% of teacher educators received in-service training on DI. Majority of them trained at their respective Colleges of teacher education and University. It infers that agents' role was less in the provision of DI training other than government institutions in the country. Based on the survey findings, more than half of the respondents have promising general knowledge about DI. About $62 \%$ to $74 \%$ of teacher educators were mentioned their developing understanding of DI following some sort of provided training. This result differs from that of Melesse (2016) survey result as indicated as too much low. The rest of a significant number have limited understanding. Moreover, about $59.7 \%$ of teacher educators had rarely differentiated for students. Regarding teacher educators' conception, unlikely to survey result, interview findings amplified how their understanding of DI was limited and superficial.

In terms of specific key elements of DI, teacher educators reported enthusiastically. They had an encouraging outlook for their students' readiness, interest and learning profile. The majority of them believed how it can impact their ways of teaching in their respective classrooms. For example, in one of the readiness concerned points, $76.1 \%$ of teacher educators confirmed that their understanding of variance in individual students' basic academic skills impacts what and how they teach. Likely, the participants regarded DI in the learning environment, content, process, and product as important. This finding is consistent with Santangelo \& Tomlinson (2012) study that a significant difference was 
not detected in terms of learning environment, content, process and product. Moreover, more than half of teacher educators showed that employing various assessment strategies was helpful although the significant share of them (near to half) not yet agree with this idea.

Contrasting to the above findings, the open-ended part of the survey and interview results show that respondents do not practice differentiated instruction at this level of education in spite of its importance in the teacher education program. Teacher educators had basic deficiencies of DI application in their respective contexts even if few of them were practising as much as possible. The majority of interviewed participants confirmed that practices of DI in their classes were almost none or very fragmentary. This means their conceptual understanding of DI and its application was quite varied while they were describing their experiences of differentiation strategies. This mismatching phenomenon might stem from inadequate training and misconception regarding DI.

Result of the study identified some major benefits of DI which realized by teacher educators who were differentiating instruction and summarized as:

- increased motivation of learners and teacher educators toward DI,

- improved relationship between learners and teachers,

- narrowing achievement gaps of prospect teachers/learners,

- increased motivation of teachers to involve in-service training, etc.

On the other hand, the study naked some persistent challenges of DI in a teacher education program and listed as:

- time-consuming nature of DI,

- lack of trained teacher educators,

- less commitment of teacher educators to apply DI,

- misunderstandings,

- large class size,

- lack of facilities in Colleges and University,

- limited access for professional development on DI topics, etc.

Consistent with this finding, Melesse (2016) study indicated that lack of experience was found to be the main factor affecting teachers in implementing DI. 


\section{CONCLUSION AND SUGGESTIONS}

Teacher educators reported that they required more training on the utilization of differentiated instruction techniques. The knowledge of using differentiated instruction is the major predictor of teachers' willingness to use the approach. This point of view is consistent with Blozowich (2001) who concluded that teachers implementing differentiated instruction require continues professional development, coupled with intensive dialogue and consultation about how differentiated instruction techniques are being implemented in the classroom (Alavinia \& Farhady, 2012).

Correspondingly, it is reasonable to propose practical DI courses to equip teacher educators adequately through pre-service teacher education programs. McKenzie (2000) noted that there was a strong need for teachers to have extensive training in the implementation of differentiated instruction (McKenzie, 2000). Teacher educators to be encouraged and accessed for supplementary reading materials in different ways of provision, like books, modules, practical guides, etc. It is a fact that once teachers have a good understanding of students' level of readiness, interests and learning profiles that they will be more likely to engage in effective and appropriate content, process, and product differentiation (Santangelo \& Tomlinson, 2012). Thus, we exhort that holding professional development activities, for example, workshops and pieces of training for teacher educators on how to implement DI strategy and provide them with practical models for the application of its specific strategies in teacher education. Likewise, awareness creation through presentations of research findings, workshops, seminars and advocating for DI to take place since the model seems recent phenomena in the country. By doing so teachers, students, heads and policymakers' motivation will be changed optimistically and misunderstandings can be avoided. Since educational activities require facilities and an adequate learning environment, Colleges and Universities should prioritize the provision of facilities for proper application of DI.

Based on this small-scaled study, we were not able to prove if, nor explore how, their knowledge and practices play out within the teacher education program. Therefore, it would be great conducting further investigation on teacher educators' knowledge and its application in higher education in Colleges of Teacher Education or Universities.

\section{REFERENCES}

Alavinia, P., \& Farhady, S. (2012). Using differentiated instruction to teach vocabulary in mixed ability classes with a focus on multiple intelligences and learning styles. International Journal of Applied Science and Technology, 2(4), 72-82.

Audet, R. H., \& Jordan, L. K. (2005). Integrating inquiry across the curriculum. Corwin Press.

Creswell, J. W. (2013). Research design: Qualitative, quantitative, and mixed methods approaches. SAGE. 
Delisle, J. R. (2015, January 7). Differentiation doesn't work-education week. Education Week. Retrieved from https://www.edweek.org/ew/articles/2015/01/07/differentiation-doesnt-work.html.

Filip, D., Mien, S., Piet Van den, B., \& David, G. (2003). Effects of problem-based learning: A meta-analysis. Learning and Instruction, 13(5), 533-568.

Gregory, G., \& Kuzmich, L. (2004). Data driven differentiation in the standards-based classroom. Thousand Oaks, Calif: Corwin Press.

John, McC. (2014). 3 Ways to plan for diverse learners: What teachers do. Retrieved from https://www.edutopia.org/blog/differentiated-instruction-ways-to-plan-johnmccarthy

Joshi, R., \& Verspoor, A. (2012). Secondary education in Ethiopia: Supporting growth and transformation. World Bank study. Washington, DC: World Bank.

Livingston, K. (2016). Developing teachers' and teacher educators' professional identity in changing contexts. European Journal of Teacher Education, 39(4), 401-402. https://doi.org/10.1080/02619768.2016.1235822.

Lund, T. (2012). Combining qualitative and quantitative approaches: Some arguments for mixed methods research. Scandinavian Journal of Educational Research, 56(2), 155-165. https://doi.org/10.1080/00313831.2011.568674.

McKenzie, J. (2000). Beyond technology: Questioning, research and the information literate school. FNO Press.

Melese, S. (2019). Instructors' knowledge, attitude and practice of differentiated instruction: The case of college of education and behavioral sciences, Bahir Dar University, Amhara region, Ethiopia. Cogent Education, 6(1). https://doi.org/10.1080/2331186X.2019.1642294.

Melesse, T. (2016). Differentiated instruction: Perceptions, practices and challenges of primary school teachers. Science, Technology and Arts Research J, 4(3), 253-264.

Merrill, M. D. (2013). First principles of instruction: Identifying and designing effective, efficient, and engaging instruction. San Francisco: Pfeiffer.

Miller, R. (2011). Vygotsky in perspective. Cambridge: Cambridge University.

MoE. (2015). Education Sector Development Programme V (ESDP V). Retrieved from https://www.pdfdrive.com/education-sector-development-programme-v-

e42233439.html.

Nordlund, M. (2003). Differentiated instruction: Meeting the needs of all students. R\&L Education. 
Santangelo, T., \& Tomlinson, C. A. (2012). Teacher educators' perceptions and use of differentiated instruction practices: An exploratory investigation. Action in Teacher Education, 34(4), 309-327. https://doi.org/10.1080/01626620.2012.717032.

Schlechty, P. C. (1997). Inventing better schools: An action plan for educational reform (Jossey Bass Education Series). Jossey-Bass.

Seifert, K., \& Sutton, R. (2011). Educational psychology. Independent.

Smets, W., \& Struyven, K. (2018). Realist review of literature on catering for different instructional needs with preteaching and extended instruction. Edu Sciences, 8(3), 113.

Subban, P., \& Round, P. (2015). Differentiated instruction at work. Reinforcing the art of classroom observation through the creation of a checklist for beginning and preservice teachers. Australian Journal of Teacher Education, 40(5). http://dx.doi.org/10.14221/ajte.2015v40n5.7.

Sultana, N., Yousuf, M. I., Din, M. N. U., \& Rehman, S. (2011). The higher the quality of teaching the higher the quality of education. Contemporary Issues in Education Research (CIER), 2(3), 59. https://doi.org/10.19030/cier.v2i3.1088.

Theisen, T. (2002). Differentiated instruction in the foreign language classroom: Meeting the Diverse Needs of All Learners. 8. The Communique, 6, 1-8.

Tomlinson, C. A. (2000). Reconcilable differences: Standards-based teaching and differentiation. Educational Leadership, 58, 6-13.

Tomlinson, C. A. (1999). The differentiated classroom: Responding to the needs of all learners. Alexandria, Va: Assoc. for Supervision and Curriculum Development.

Tomlinson, C. A. (2001). At work in the differentiated classroom. Facilitator's guide. Alexandria, Va.: Association for Supervision and Curriculum Development.

Tomlinson, C. A. (2005). How to differentiate instruction in mixed-ability classrooms. Alexandria: Association for Supervision \& Curriculum Development.

Tomlinson, C. A., Brighton, C., Training, H., Callahan, C. M., Moon, T. R., Brimijoin, K., ... Reynolds, T. (2003). Differentiating instruction in response to student readiness, interest, and learning profile in academically diverse classrooms: A review of literature. Journal for the Education of the Gifted, 27(2-3), 119-145. https://doi.org/10.1177/016235320302700203.

Tomlinson, C. A., \& Imbeau, M. B. (2011). Leading and managing a differentiated classroom. Moorabbin, Vic.: Hawker Brownlow Education.

Tomlinson, C. A., \& McTighe, J. (2006). Integrating differentiated instruction \& understanding by design. Assoc for Supervision and Curriculum Development.

Vygotskij, L. S. (1986). Thought and language. Cambridge, MA: The MIT Press. 
Wen, Q. (2004). Applied linguistics research methods and thesis writing [应用语言学 研究方法与论文写作]. Beijing: Foreign Language Teaching and Research Press.

Wilson, S. M., \& Peterson, P. L. (2006). Theories of learning and teaching what do they mean for educators? Washington, DC: National Education Association. 